DOI:

УДК 349.6

\title{
Ольга Зигрій,
}

кандидат економічних наук,

доиент кафедри цчивільного права і процесу

Західноукраїнського національного

університету

ORCID: https://orcid.org/0000-0001-7092-5306

\section{Світлана Крамарчук,}

кандидат економічних наук,

доиент кафедри менеджменту,

публічного управління та персоналу

Західноукраӥнського національного

університету

ORCID: https://orcid.org/0000-0001-5130-9954

\section{Тетяна Крамарчук,}

магістрант юридичного факультету

Західноукраїнського національного

університету

\section{ПОНЯТТЯ ТА СТРУКТУРА ЕКОЛОГІЧНОГО ОБОВ'ЯЗКУ}

Розкрито актуальність та значущість приділення належної уваги дослідженню поняття та структури екологічного обов'язку. Проаналізовано наукові точки зору щодо поняття та структури екологічного обов'язку, виокремлено основні характеристики та особливості екологічних обов'язків. Досліджено основні концептуальні підходи до розкриття змісту екологічного юридичного обов'язку. Розвиваючи погляди науковців, визначено принципи, на яких грунтуються екологічні обов'язки.

Ключові слова: екологічні обов 'язки, правовий статус, юридичні обов 'язки структура, складові елементи, екологічне право.

Бібл.: 10.

\section{Зыгрий О., Крамарчук С., Крамарчук $T$.}

Понятие и структура экологической обязанности

Раскрыты актуальность и значимость уделения должного внимания исследованию понятия и структуры экологических обязанностей. Проанализированы научные точки зрения относительно понятия $и$ структуры экологической обязанности, выделены основные характеристики и особенности экологических обязанностей. Исследованы основные кониептуальные подходы к раскрытию содержания экологического юридической обязанности. Развивая взгляды ученых, определены принщипы, на которых основываются экологические обязанности.

Ключевые слова: экологические обязанности, правовой статус, юридические обязанности, структура, составные элементы, экологическое право.

\section{Zyhrii O., Kramarchuk S., Kramarchuk T.}

The concept and structure of environmental responsibility

Environmental duty is a way of enforcing environmental rights, where their effectiveness is conditional on reality. If environmental law is the sphere of power and will of the individual, then environmental duty is the sphere of necessity and subordination.

It is important that the environmental responsibilities are assigned to the obligated person, who must choose one of the legally prescribed options. She must take certain actions or refrain from them.

Legal obligations must be exercised within or outside the legal relationship. Within the legal relationship, the legal obligation is subject to specification: the authorized party is determined, the object is defined, the content and limits of the behavior of the obligated person are specified.

A feature of environmental responsibilities is their predominant implementation outside the legal relationship. 
Thus, legal obligations are based on the principles of priority of public interest over individual. This is manifested as follows:

1) sometimes the participants of ecological and legal relations are not free to impose legal obligations on them and determine their scope;

2) legal obligations are defined by law and do not provide for regulation by the participants of environmental legal relations;

3) the model of correct behavior is formed not by the bearers of legal obligations, but by the state in the person of authorized subjects of public authority;

4) fulfillment of a legal obligation in the field of environmental law is carried out with the help of an imperative nature, the provision of force of state coercion, the focus on achieving the common good;

5) bearers of environmental obligations are not free to choose to perform them, the state controls the implementation of legal obligations in the field of environmental rights. Failure to do so leads to bringing the violator to justice;

6) if in private law the decision on whether to bring the violator to justice for failure to fulfill a legal obligation depends almost entirely on the opinion of the other party, in environmental law the issue of prosecution and the magnitude of this responsibility is decided by the commissioners. bodies within their powers;

7) there are rights in environmental legislation that are considered as responsibilities.

Keywords: environmental responsibilities, legal status, legal responsibilities, structure, components, environmental law.

Постановка проблеми. В умовах посиленого використання природних ресурсів та підвищеної уваги до екологічної обстановки важливого значення набуває проблема чіткого визначення в законодавстві екологічних обов'язків громадян. Забезпечення та реалізація контролю за дотриманням екологічних обов'язків громадян мають стати одним із пріоритетних напрямів державної екологічної політики в Україні, а також предметом наукових досліджень у цій сфері.

Аналіз наукових досліджень та публікацій. Дослідженню екологічних обов'язків громадян присвячено праці українських науковців, а саме: В. Андрейцева, Г. Анісімової, В. Попова, М. Краснової, О. Колбасова, Н. Малишевої, Т. Слинько та ін. Однак сутність поняття екологічного обов'язку громадян у різних джерелах трактують дещо по-різному, а також не повною мірою досліджено структуру екологічних обов'язків громадянина.

Мета статті полягає в з'ясуванні визначення поняття екологічних обов'язків громадянина на основі аналізу нормативно-правових актів природоохоронного спрямування та уточнення їхньої структури.

Виклад основного матеріалу дослідження. Екологічний обов'язок $€$ важливим способом забезпечення екологічних прав, умовою їхньої ефективності та реальності. Якщо екологічне право $є$ сферою влади й волі індивіда, то екологічний обов'язок є сферою необхідності та підпорядкування [3, с. 71].

Екологічні обов'язки належать зобов'язаній особі, яка має обрати один із передбачених правом варіант поведінки, тобто здійснювати певні дії або утримуватись від них. У цьому випадку право визначає межі необхідної поведінки. Серед головних характеристик екологічних обов'язків варто виокремити такі:

1) екологічні обов'язки $є$ елементом механізму регулювання правових екологічних відносин, за допомогою якого визначається, яким чином з погляду права має діяти особа у певних життєвих умовах і які наслідки на неї чекають у разі порушення відповідних вимог;

2) екологічні обов'язки закріплюють зразок (еталон, стандарт) правомірної поведінки громадянина, встановлюють наслідки для особи в разі ії порушення, тобто ці обов'язки слугують правовим критері$\epsilon м$ щодо оцінювання поведінки особи як необхідної чи забороненої та для визначення можливих правових наслідків;

3) виконання екологічних обов'язків забезпечуються погрозою застосування державного примусу. Останній виконує, перш за все, роль гарантії, що необхідна на випадок можливих порушень норми. Вирішальним у такому разі має бути варіант добровільного дотримання юридичних правил, що базується на внутрішньому переконанні особи в правильності (доцільності та справедливості) покладених на неї екологічних обов'язків, сприйманні їх як легітимних вимог. Але незважаючи на вищесказане, їх обов'язковість підтримується силою державного впливу та погрозою застосування примусу;

4) екологічні обов'язки мають певні форми свого зовнішнього вираження, тобто закріплюються в спеціальних джерелах: правових звичаях, нормативно-правових актах, судових прецедентах тощо. Саме джерела права роблять доступними для громадськості та суб' єктів господарювання стандарти правомірної поведінки у галузі екологічних правовідносин і наслідки в разі відхилення від них. Норми екологічного права в нашій країні закріплюються здебільшого в нормативно-правових актах; 
Цивільне право і цивільний процес. Сімейне право. Трудове право. Міжнародне приватне право. Господарське право. Господарсько-процесуальне право.

5) у змісті екологічних обов'язків переважає публічно-правовий елемент. У приватному й публічному праві сформовано різні моделі взаємодії елементів суб'єктивного права та юридичного обов'язку. Основними з них є такі три моделі: перша - суб'єктивне право на власні дії кореспондує обов'язок вчиняти певні дії; друга - суб'єктивне право на дію іншої особи відповідає обов'язку вчинити конкретну дію; третя - суб'єктивне право на власні дії веде до обов'язку утриматися від вчинення певної дії. В практиці публічного права, крім означених вище трьох моделей взаємозв'язку елементів юридичних прав та обов'язків, наявні ще дві: 1) обов'язку вчиняти конкретні дії, з одного боку, кореспондує повинність щодо вчинення певних дій, з іншого боку; 2) обов'язку вчиняти конкретні дії відповідає зобов'язання утримуватися від вчинення певних дій.

Отож, реалізація юридичних обов'язків, як і реалізація суб’єктивних прав, має відбуватися або в межах правовідносин, або поза ними. Відповідно, у межах правовідносин юридичний обов'язок, визначений за допомогою норм права, підлягає конкретизації: визначається уповноважена сторона, окреслюється об'єкт, уточнюється зміст і межі поведінки зобов'язаної особи.

Особливістю екологічних обов'язків $є$ їх переважна реалізація поза правовідносинами. Зокрема, до таких обов'язків належать:

- не знищувати і не пошкоджувати газони, самовільно не знищувати та не висаджувати дерева, кущі тощо; «не вивозити і не звалювати в не відведених для цього місцях відходи, траву, гілки, деревину, листя» [4];

- «утримуватися від торгівлі лікарськими і декоративними видами рослин та їх частинами (корені, стебла, плоди тощо), зібраними в порядку загального використання природних рослинних ресурсів» [5];

- «не поводитися жорстоко із тваринами, сприяти відтворенню відновлюваних об' єктів тваринного світу» [6];

- «забезпечувати охорону, захист, відтворення і підвищення продуктивності лісових насаджень, посилення їхніх корисних властивостей та покращення родючості грунтів, виконувати інші заходи відповідно до вимог лісового законодавства; дотримуватися правил і норм використання лісових ресурсів; вести лісове господарство та використовувати лісові ресурси способами, які не завдають шкоди навколишньому природному середовищу» тощо [7].

Оскільки системність права виявляється не лише на рівні юридичних норм, а також і на інших рівнях, суб'єктивні юридичні права й обов'язки становлять «систему, тобто сукупність елементів, що знаходяться у відносинах (зв'язках) між собою і утворюють певну цілісність» [10, с. 427].

Сьогодні в наукових юридичних працях представлено кілька підходів щодо розкриття змісту екологічного юридичного обов'язку.

Першим прийнято вважати так званий «поелементний» підхід. Основою його є виокремлення у юридичному обов'язку певних частин за аналогією із правомочностями, які становлять суб'єктивне право. Проте визначеності щодо кількості й змісту цих елементів у науковій літературі немає. Поелементний підхід отримав розвиток ще у дореволюційному правознавстві. Науковець Ф. В. Тарановський поділяв всі юридично обов'язкові дії на три групи:

1) щось робити;

2) чогось не робити;

3) щось терпіти.

Дослідник вважав, що до кожного із зазначених обов'язків $є$ відповідне чуже право. Така модель сутності юридичного обов'язку грунтується на принципах протилежності поведінки зобов'язаного та уповноваженого суб'єкта, а також спирається на положення про те, що юридичні обов'язки $є$ засобом задоволення інтересів уповноваженої особи [9, с. 156].

С. С. Алексєєв виокремлює в структурі обов'язку інші три елементи (необхідності). Окрім обов' язку діяти й обов'язку дотримуватися приписів, він вказує ще на одну необхідність, а саме - обов'язок нести відповідальність, себто зазнавати державно-примусового впливу за здійснене правопорушення [1, с. 130].

Позицію С. С. Алексєєва поділяє С. А. Комаров. Вчений виокремлює три форми, в яких може реалізовуватися правовий обов'язок:

1) пасивна поведінка - утримання від заборонених дій;

2) активна поведінка - здійснення конкретних дій;

3) заходи юридичної відповідальності - отримання обмежень у правах особистого, майнового чи організаційного характеру. 
Поелементний підхід до змісту юридичного обов'язку представлений також у наукових дослідженнях М. І. Матузова та Б. М. Семенко, які виокремили такі «чотири елементи обов’язку:

1) необхідність здійснення певних дій;

2) необхідність утриматися від певних дій;

3) необхідність вимагати здійснення або нездійснення певних дій;

4) необхідність відповідати за невчинення певних дій» [8, с. 33].

Наведений підхід до характеристики екологічних обов'язків видається нам найбільш обгрунтованим. Відповідно, екологічні обов'язки передбачають:

а) необхідність вчинення певних дій або утримання від них;

б) необхідність реагувати на законні вимоги вповноваженої особи;

в) необхідність не чинити перешкод уповноваженій особі користуватися тими благами, на які вона має законне право;

г) необхідність приймати заходи державного примусу в випадку невиконання своїх обов'язків.

Доцільно зазначити, що в науковій юридичній літературі означений елемент юридичного обов'язку формулюється дещо вужче через вказівку лише на необхідність зазнавання заходів юридичної відповідальності. На нашу думку, порушення екологічних обов'язків, крім юридичної відповідальності, також може мати наслідками застосування заходів для припинення правопорушень, а також прийняття заходів правового захисту, або ж правовідновних заходів. Так, засобами правового захисту може бути відшкодування нанесеної шкоди, вилучення незаконно добутих природних ресурсів та виготовленої із них продукції, конфіскація засобів з допомогою яких здійснено правопорушення.

За іншою концепцією зміст юридичного обов'язку складається із обов'язків діяти та утримуватися від дій. Прихильником такого підходу є В. С. Ем. Дослідник поділяє обов'язки за своїм змістом на обов'язки активного та пасивного типу. У складі обов' язків пасивного типу В. С. Ем виокремлює такі елементи: імпліцитні заборони та обов'язки-принципи.

Імпліцитні заборони - це заборони, які вводяться до складу позитивного обов'язку з допомогою встановлення санкцій за його невиконання. Цей вид заборон грунтується на тому, що позитивні обов'язки та заборони є взаємно визначеними. Підтвердженням цього тезису є глава 7 КУПАП, яка охоплює велику кількість складів адміністративних порушень, об'єктом яких $є$ навколишнє природне середовище. Фактично цим законодавець визначає заборонені варіанти поведінки, а отже, вказує на обов'язок утриматися від певних дій (не псувати земельні угіддя, не забруднювати їх радіоактивними й хімічними речовинами, нафтопродуктами, виробничими й іншими відходами, неочищеними стічними водами, вживати заходи зі знищення бур'янів; не забруднювати й не засмічувати водні ресурси; не здійснювати незаконну порубку та пошкодження дерев і чагарників тощо).

Заборону на найнебезпечніші види дій щодо навколишнього природного середовища подано у Кримінальному кодексі України в вигляді відповідних складів злочинів. Варто зазначити, що як адміністративні, так і кримінальні правові порушення належать до правопорушень у сфері публічного права. Основною їхньою відмінністю від приватно-правових порушень $\epsilon$ те, що в приватно-правових відносинах вирішення питання щодо того, чи притягати порушника до юридичної відповідальності, практично повністю залежить від думки другої сторони відносин. До прикладу, покупець, що придбав товар із певними недоліками, самостійно має вирішити, чи звертатися йому до продавця з приводу обміну товару на більш якісний, чи повернути товар та вимагати повернення сплачених коштів, а за наявності обгрунтованих підстав - відшкодування завданої шкоди. І лише в випадку виникнення спору щодо самого факту здійснення правопорушення або щодо визначеної міри відповідальності його буде направлено для вирішення в суді.

Ті самі види відповідальності, які належать до публічно-правових (а порушення екологічних обов'язків належать саме до цієї групи), навпаки орієнтовані на те, щоб незалежно від того, яку позицію займе особа, чиї інтереси були порушені, питання притягнення до відповідальності та міри цієї відповідальності вирішувалися лише уповноваженими органами.

Обов'язки-принципи - це обов'язки, функція яких виявляється шляхом встановлення загальної заборони щодо порушення закону. До цих обов'язків належать названі у статті 12 Закону України «Про охорону навколишнього природного середовища» такі зобов'язання: берегти природу, раціонально використовувати ії ресурси; здійснювати діяльність 3 дотриманням вимог екологічної безпеки; не порушувати екологічні права й законні інтереси інших суб'єктів тощо.

Наступний підхід до розкриття структури екологічного обов'язку базується на аналогії із виробленою теорією права, структурою права. Так, за класифікацією Р. Алексі, права-вимоги є «трьохкомпонент- 
Цивільне право і цивільний процес. Сімейне право. Трудове право. Міжнародне приватне право. Господарське право. Господарсько-процесуальне право.

ними відносинами, першим елементом у яких є бенефіціар, або носій права (a), другим - адресат права (b), а третім - предмет права (S). Якщо а має по відношенню до b право на S, то b має обов'язок щодо $\mathrm{S}$ перед a, і навпаки» [2, с.122].

Якщо право у своїй структурі зазвичай має адресата, структура обов'язку часто може обмежуватися такими елементами як предмет обов'язку і носій обов'язку, не маючи адресата.

Щодо носія екологічного обов'язку, то для того, щоб певна особа могла мати суб'єктивні права й юридичні обов'язки, вона має бутиьправоздатною, а для того, щоби самостійно здобувати й реалізовувати свої суб'єктивні права та юридичні обов' язки, - ще й дієздатною. Якщо особа є правоздатною, але не дієздатною (наприклад, через свій вік чи стан здоров'я), то у правовідносини разом із нею вступає інша особа, що володіє дієздатністю й виступає їі представником.

Суб’єкт права повинен відповідати таким ознакам:

1) бути зовнішньо відокремленим;

2) бути персоніфікованим (індивідуалізованим);

3) мати свідомість, могти самостійно виражати свою волю;

4) бути суб'єктом права, який може бути визнаним у відповідній правовій системі.

Нормативно-правові акти, що стосуються екології, зазвичай, не містять спеціальних положень і приписів щодо визначення правосуб'єктності - як екологічної, так і їі різних видів (земельної, водної тощо).

Екологічна правоздатність - є невід'ємною властивістю кожного індивіда, який є правоздатним протягом свого життя незалежно від здоров'я та віку. Це можливість суб' єкта мати певні права та обов'язки від народження до смерті. Ці права є невід’ємними й невідчужуваними, вони забезпечують в екології єдність приватних та публічних інтересів. Зміст екологічної правоздатності кожної особи завжди є конкретним, але також динамічним, тому що залежить від характеру відносин та специфіки правового режиму.

Висновки. Аналіз наведених вище теоретико-методологічних положень науковців щодо розуміння сутності екологічного обов’язку та його структури дав змогу зробити такі висновки:

Екологічні обов'язки характеризуються такими ознаками:

вони є елементом механізму регулювання правових екологічних відносин; 2) закріплюють зразок (еталон, стандарт) правомірної поведінки громадянина, встановлюють наслідки для особи в разі їі порушення, слугують правовим критерієм щодо оцінювання поведінки особи як необхідної чи забороненої та для визначення можливих правових наслідків; 3) виконання екологічних обов'язків забезпечуються погрозою застосування державного примусу; 4) мають певні форми свого зовнішнього вираження, тобто закріплюються в спеціальних джерелах: правових звичаях, нормативно-правових актах, судових прецедентах тощо; 5) в їхньому змісті переважає публічно-правовий елемент.

В екологічному праві юридичні обов’язки грунтуються на принципах пріоритету суспільного інтересу над індивідуальним. Зокрема, це виявляється у тому, що: переважно учасники еколого-правових відносин не є вільними в покладенні на них юридичних обов' язків та визначенні їхнього обсягу; юридичні обов'язки в екологічному праві, зазвичай, визначаються нормативно і не передбачають регулювання із сторони учасників екологічних правових відносин; модель правильної поведінки формують не носії юридичних обов'язків, а держава в особі уповноважених суб'єктів публічної влади; виконання юридичного обов'язку в сфері екологічного права здійснюється зазвичай за допомогою їхнього імперативного характеру, забезпеченості силою державного примусу, направленості на досягнення загальних благ; носії екологічного обов'язку не є вільні у виборі щодо їхнього виконання, держава скурпульозно контролює за виконанням юридичного обов' язку в сфері екологічних прав, невиконання веде до притягнення порушника до юридичної відповідальності; якщо у приватно-правових відносинах вирішення питання щодо того, чи притягувати порушника до юридичної відповідальності за невиконання юридичного обов’ язку, практично повністю залежить від думки другої сторони відносин, то в екологічному праві питання щодо притягнення до відповідальності та величини цієї відповідальності вирішують уповноважені органи у межах своїх повноважень; в екологічному законодавстві є права, які розглядаються як обов’язки.

\section{Список використаних джерел}

1. Алексеев С. С. Структура советского права. Москва : Статут, 2010. С. 7-224.

2. Алексі Р. Існування прав людини. Право Украӥни. 2011. № 8. С. 121-130.

3. Екологічне право України : підручник для студентів юрид. вищ. навч. закладів / А. П. Гетьман, М. В. Шульга, В. К. Попов та ін. ; за ред. А. П. Гетьман та М. В. Шульги. Харків : Право, 2009. 328 с. 
4. Про благоустрій населених пунктів : Закон України від 06.09.2005 p. № 2807-IV. Офіційний вісник України. 2005. № 40. Стор. 12. Ст. 2528.

5. Про рослинний світ : Закон України від 09.04.1999 р. № 591-XIV. Офіційний вісник України. 1999. № 18. Стор. 23.

6. Про тваринний світ : Закон України від 13.12.2001 р. № 2894-III. Офіиійний вісник України. 2002. № 2. Стор. 40. Ст. 47.

7. Лісовий кодекс України від 21.01.1994 р. № 3852-ХІІ. Відомості Верховної Ради Украӥни. 1994. № 17. Стор. 443. Ст. 99.

8. Тарановский Ф. В. Учебник энциклопедии права. Юрьев : Тип. К. Маттисена, 1917. 537 с.

9. Философский словарь / под ред. И. Т. Фролова. 5-е изд. Москва : Политиздат, 1986. 590 с.

\section{References}

1. Alekseyev, S. S. (2010). Struktura sovetskogo prava [Structure of Soviet law]. Moscow: Statut [in Russian].

2. Aleksi, R. (2011). Isnuvannia prav liudyny [The existence of human rights]. Pravo Ukrainy - Law of Ukraine, 8, 121-130 [in Ukrainian].

3. Hetman, A. P. \& Shulhy, M. V.(Eds.) (2009). Ekolohichne pravo Ukrainy [Environmental Law of Ukraine]. Kharkiv: Pravo [in Ukrainian].

4. Zakon Ukrainy «Pro blahoustrii naselenykh punktiv» [Law of Ukraine «On improvement of settlements»] (2005). Ofitsiinyi visnyk Ukrainy - Official Bulletin of Ukraine, 40 [in Ukrainian].

5. Zakon Ukrainy «Pro roslynnyi svit» [Law of Ukraine «On flora»] (1999). Ofitsiinyi visnyk Ukrainy - Official Bulletin of Ukraine, 18 [in Ukrainian].

6. Zakon Ukrainy «Pro tvarynnyi svit» [Law of Ukraine «On the animal world»] (2002). Ofitsiinyi visnyk Ukrainy - Official Bulletin of Ukraine, 40 [in Ukrainian].

7. Lisovyi kodeks Ukrainy [Forest Code of Ukraine] (1994). Vidomosti Verkhovnoi Rady Ukrainy - Bulletin of the Verkhovna Rada of Ukraine, 17 [in Ukrainian].

8. Taranovskii, F. V.(1917). Uchebnik entsiklopedii prava [Textbook of the encyclopedia of law]. Yuryev: Tip. K. Mattisena [in Russian].

9. Frolova. I. T. (Eds.). (1986). Filosofskii slovar [Philosophical Dictionary]. Moscow: Politizdat [in Russian].

Стаття надійшла до редакції 07.10.2020. 